\title{
Interaksi Investasi, Dana Pihak Ketiga dan Pembiayaan Perbankan Syariah Terhadap Pertumbuhan Ekonomi di Sumatera Utara
}

\author{
Sugianto ${ }^{1)}$, Muhammad Yafiz ${ }^{2)}$, Anita Khairunnisa ${ }^{3 *}$ \\ ${ }^{1,2,3}$ FEBI Universitas Islam Negeri Sumatera Utara, Medan, Indonesia. \\ *Email Korespondensi: anitakhairunnisa42@gmail.com
}

Economic growth is a picture to see the progress of economy a country or region, as measured with the amount of data on Gross Domestic Product (GDP) or data on Gross Regional Domestic Product (GRDP). The purpose of this study is to analyze the independence of the variables that affect economic growth, such as Domestic Investment (DI), Foreign Direct Investment (FDI), Third Party Funds (TPF) and Islamic Banking Financing. The research method uses a quantitative approach with secondary data in time series with the Vector Error Correction Model (VECM) methods and uses the help of Eviews 9 program. This study uses a sample from 2010 to 2020. The results of this study indicate that in the long run the variables of DI, FDI and Financing Islamic Banking have a positive and significant effect on the GRDP of North Sumatra, while the TPF Islamic Banking variable has a negative effect on the GRDP of North Sumatra. In the short term, the DI variable significantly affects the FDI. This study suggests that in order to advance the economy of a region, North Sumatra government should encourage and support activities carried out by DI and FDI, as well as financial institutions such as Islamic banking, which are primarily activities in the form of Third Party Funds and financing. The existence of financing disbursed by Islamic banking can provide capital assistance to business actors, so as to increase economic growth.

\section{Keywords: GRDP, DI, FDI, TPF, Financing Islamic Banking}

Saran sitasi: Sugianto., Yafiz, M., \& Khairunnisa, A. (2021). Interaksi Investasi, Dana Pihak Ketiga dan Pembiayaan Perbankan Syariah Terhadap Pertumbuhan Ekonomi di Sumatera Utara. Jurnal Ilmiah Ekonomi Islam, 7(02), 1091-1100. doi: http://dx.doi.org/10.29040/jiei.v7i2.2601

DOI: http://dx.doi.org/10.29040/jiei.v7i2.2601

\section{PENDAHULUAN}

Kemajuan suatu negara dapat dilihat dari tingkat pertumbuhan ekonominya. Pertumbuhan ekonomi diukur dari besarnya data Gross Domestic Product (GDP) yang mengukur pendapatan total setiap orang dalam perekonomian suatu negara atau daerah (Hasyim, 2016). Indonesia merupakan negara yang masuk ke dalam jajaran negara G-20, yaitu negara dengan tingkat GDP terbesar di dunia (Rama, 2017). Menurut Todaro dan Smith GDP adalah total outpun akhir barang dan jasa yang dihasilkan perekonomian suatu negara, di dalam wilayah negara tersebut, oleh penduduk atau bukan penduduk, tanpa melihat alokasinya baik milik domestik maupun milik luar negeri (Smith, 2011).

Produk Domestik Regional Bruto/PDRB adalah jumlah nilai barang dan jasa yang dihasilkan oleh seluruh unit ekonomi di dalam wilayah domestik untuk digunakan sebagai konsumsi masyarakat. Sumatera Utara merupakan provinsi dengan jumlah penduduk terbesar keempat di Indonesia setelah Jawa Barat, Jawa Timur dan Jawa Tengah. Jumlah penduduk Sumatera Utara berdasarkan sensus penduduk pada tahun 2010 sebesar 12.982,204 jiwa, dengan mayoritas penduduk menganut agama Islam sekitar 66,09\%. Kondisi ini seharusnya memberikan dampak positif untuk tingkat pertumbuhan ekonomi Sumut. Di mana, banyaknya jumlah pertumbuhan penduduk dapat berdampak pada perubahan struktur perekonomian suatu daerah (Devi Valeriani, et.al., 2019).

Menurut Jhingga proses pertumbuhan ekonomi suatu negara atau daerah dipengaruhi oleh dua macam faktor, yaitu faktor ekonomi dan faktor nonekonomi. Faktor ekonomi terdiri dari sumber alam, akumulasi modal, organisasi, kemajuan teknologi, pembagian 
kerja dan skala produksi. Sedangkan faktor nonekonomi terdiri dari faktor sosial, faktor manusia, faktor politik dan administratif (Jhingan, 2018). Akumulasi modal atau pembentukan modal adalah investasi dalam bentuk barang-barang modal yang dapat menaikkan stok modal, output nasional dan pendapatan nasional. Penanaman modal terbagi menjadi dua macam yaitu Penanaman Modal Dalam Negeri (PMDN) dan Penanaman Modal Asing (PMA) yang dapat berperan dalam meningkatkan pertumbuhan ekonomi (Kairupan, 2013).

Organisasi merupakan faktor ekonomi yang sifatnya melengkapi modal, buruh dan meningkatkan produktivitas. Di dalam organisasi, bank adalah lembaga keuangan terpenting yang memberikan sumbangan kepada pertumbuhan ekonomi. Di mana,

bank dapat memberikan bantuan keuangan kepada pelaku usaha. Dalam perkembangannya, kegiatan bisnis perbankan terbagi menjadi dua yaitu bank konvensioanl dan bank syariah (Masykuroh et al., 2020). Perbedaanya, bank konvensioanl menerapkan bunga atas simpanan yang diterima dan kredit yang diberikan. Sedangkan bank syariah tidak mengenal sistem bunga, tetapi menerapkan sistem bagi hasil dan akad-akad lainnya yang sesuai dengan prinsip syariah (Muhammad Hafizh, 2019). Berikut data realisasi Penanaman Modal Dalam Negeri (PMDN), realisasi Penanaman Modal Asing (PMA), Dana Pihak Ketiga (DPK) Perbankan Syariah, pembiayaan Perbankan Syariah dan Produk Domestik Regional Bruto (PDRB) yang ada di Sumatera Utara dari tahun 2015 sampai dengan tahun 2020:

Tebel 1

Realisasi PMDN, Realisasi PMA, DPK Perbankan Syariah, Pembiayaan Perbankan Syariah dan PDRB Di Sumatera Utara dari Tahun 2015-2020

\begin{tabular}{||c|c|c|c|c|c|c|}
\hline \multirow{2}{*}{ Tahun } & \multicolumn{2}{|c|}{ Investasi } & \multicolumn{2}{c|}{ Perbankan Syariah } & \multicolumn{2}{c|}{ Pertumbuhan Ekonomi } \\
\cline { 2 - 7 } & $\begin{array}{c}\text { PMDN } \\
\text { (Rp. Milyar) }\end{array}$ & $\begin{array}{c}\text { PMA } \\
\text { (US\$ Juta) }\end{array}$ & $\begin{array}{c}\text { DPK } \\
\text { (Rp. Milyar) }\end{array}$ & $\begin{array}{c}\text { Pembiayaan } \\
\text { (Rp. Milyar) }\end{array}$ & $\begin{array}{c}\text { PDRB } \\
\text { (Rp. Milyar) }\end{array}$ & \% \\
\hline $\mathbf{2 0 1 5}$ & $4.287,42$ & $1.246,1$ & 7.350 & 7.717 & $440.955,85$ & 5,10 \\
$\mathbf{2 0 1 6}$ & $4.954,83$ & $1.014,7$ & 9.048 & 8.643 & $463.775,46$ & 5,18 \\
$\mathbf{2 0 1 7}$ & $11.683,64$ & $1.514,9$ & 10.647 & 9.521 & $487.531,23$ & 5,12 \\
$\mathbf{2 0 1 8}$ & $8.371,82$ & $1.227,6$ & 11.997 & 10.404 & $512.765,63$ & 5,18 \\
$\mathbf{2 0 1 9}$ & $19.749,00$ & 379,5 & 13.519 & 11.838 & $539.526,60$ & 5,22 \\
$\mathbf{2 0 2 0}$ & $18.189,50$ & 974,8 & 15.201 & 12.277 & $533.746,36$ & $-1,07$ \\
\hline
\end{tabular}

Sumber: https://sumut.bps.go.id dan www.ojk.go.id, diolah

Berdasarkan tabel 1 di atas dapat dilihat bahwa laju pertumbuhan ekonomi Sumatera Utara dalam enam tahun terakhir mengalami fluktuasi dari tahun 2015 sampai dengan 2020. Pada tahun 2018 jumlah realisasi PMDN maupun PMA mengalami penurunan, sedangkan pendanaan perbankan syariah, pembiayaan perbankan syariah dan PDRB Sumatera Utara mengalami peningkatan dari tahun 2017. Pada tahun 2019 jumlah realisasi PMDN mengalami peningkatan sebesar $70,68 \%$, yang mana pada tahun sebelumnya yaitu 2018 mengalami penurunan, sedangkan untuk realisasi PMA sejak tahun 2018 mengalami penurunan sampai pada tahun 2019 penurunan PMA mencapai $72,7 \%$, sementara pendanaan perbankan syariah, pembiayaan perbankan syariah dan PDRB Sumatera Utara mengalami peningkatan. Pada tahun 2020 perekonomian Sumatera Utara mengalami penurunan dampak dari pandemi covid-19 yang terjadi di seluruh dunia termasuk Indonesia dan Sumatera Utara sebagai provinsi di dalamnya. PDRB Sumut tahun 2020 mengalami penurunan dengan laju pertumbuhan ekonomi yang mengalami kontraksi sebesar $-1,07 \%$ dibandingkan dengan tahun 2019. Hal yang sama juga terjadi pada PMDN yang juga mengalami penurunan, sedangkan PMA, pendanaan dan pembiayaan perbankan syariah menunjukkan adanya peningkat dari tahun 2019.

Dari hasil penelitian yang dilakukan oleh Claire Emilienne Wati Yameogo dan Joseph Ayoola Omojolaibi menyatakan bahwa FDI secara signifikan dapat meningkatkat pertumbuhan dalam jangka panjang, dengan adanya kontribusi berupa sumber modal eksternal yang dapat membantu meningkatkan tabungan domestik dan mendorong pertumbuhan ekonomi melalui penciptaan lapangan kerja dan transfer teknologi (Emilienne et al., 2020). Bonaraja Purba juga menjelaskan bahwa Penanaman Modal Dalam Negeri/PMDN dan Penanaman Modal Asing/PMA memiliki pengaruh yang positif dan signifikan terhadap pertumbuhan ekonomi. Di mana 
kegiatan penanaman modal akan menghasilkan investasi yang akan terus menambah stok modal dan selanjutnya akan meningkatkan produktivitas serta kapasitas dan kualitas produksi, sehingga pada akhirnya akan dapat mendorong pertumbuhan ekonomi (Santoso, dkk., 2020); (Purba, 2020). terhadap PDB adalah Khoirul Ifa dan Fitria Ardiansyah (2019), Adinda Putri Hapsari dan Deden Dinar Iskandar (2018), dan Imamudin Yuliadi (2020).

Menurut Cooray dalam penelitian yang dilakukan oleh Moh. Herman Eko Santoso dan Mohamad Soleh Nurzaman menyatakan bahwa terdapat hubungan positif antara lembaga keuangan keuangan menyalurkan dana dari penabung ke peminjam, maka sistem ini akan berperan penting dalam proses pertumbuhan ekonomi (Tho'in \& Prastiwi, 2019); (Nurzaman, 2020). Dari hasil penelitian yang dilakukan oleh Salahuddin El Ayyubi, et.al., menyatakan bahwa pengaruh DPK terhadap PDB berpengaruh negatif dan signifikan, di mana ketika nilai suku bunga DPK pada bank konvensional meningkat, maka nasabah perbankan syariah akan memindahkan tabungan mereka pada perbankan konvensional (Ayyubi et al., 2019). Penelitian yang dilakukan oleh Muhammad Yasir Saeed, et. al., menyatakan bahwa pembiayaan bank syariah memiliki pengaruh positif terhadap pertumbuhan ekonomi, baik dalam jangka panjang maupun jangka pendek (Saeed et al., 2020). Peneliti lainnya yang juga meneliti pengaruh DPK dan pembiayaan bank syariah terhadap pertumbuhan ekonomi adalah Hazimi Foziah, et.al. (2020), Purwanto dan Fuad Yanuar A.R (2017), Mardalena dan Suhel (2015) dan Muhammad Nasir (2020).

Berdasarkan data dan uraian sebelumnya, peneliti tertarik untuk meneliti interaksi investasi, dana pihak Peneliti lainnya yang telah meneliti pengaruh investasi dan pertumbuhan ekonomi. Di mana ketika sistem

ketiga dan pembiayaan Perbankan Syariah terhadap pertumbuhan ekonomi di Sumatera Utara.

\section{METODE PENELITIAN}

\subsection{Pendekatan dan Metode Penelitian}

Pendekatan dalam penelitian ini menggunakan pendekatan kauntitatif dengan metode Vactor Autoregression (VAR) yang dikembangkan oleh Sims pada tahun 1980. VAR merupakan salah satu metode untuk data time series yang sering digunakan dalam penelitian, terutama dibidang ekonomi. Metode VAR disebut sebagai model yang a-teoritis atau tidak berlandaskan pada teori ekonomi tertentu (Ascarya, n.d.).

\subsection{Jenis dan Sumber Data}

Data dalam penelitian ini adalah data sekunder berupa data time series, yang bersumber dari website Badan Pusat Statisti (BPS) Sumatera Utara dan website Otoritas Jasa Keuangan (OJK) Regional 5 Sumatera Utara.

\subsection{Populasi dan Sampel}

Populasi dalam penelitian ini adalah seluruh laporan perkembangan perekonomian Sumatera Utara dan perbankan syariah Sumatera Utara dari tahun 1992 secara bulanan dengan jumlah 348 populasi. Sampel dalam penelitian ini adalah purposive sampling dengan mengambil sampel berdasarkan tujuan dan pertimbangan tertentu. Sampel yang diambil mulai dari tahun 2010 sampai dengan tahun 2020 secara bulanan dengan jumlah 132 sampel, yang diolah dengan menggunakan software Eviews 9. Hal ini karena data masih mudah diperoleh dan relevan untuk saat ini.

\subsection{Definisi Operasional}

Adapun variabel dalam penelitian ini adalah sebagai berikut:

Tabel 2

Definisi Operasional

\begin{tabular}{|l|l|}
\hline \multicolumn{1}{|c|}{ Variabel } & \multicolumn{1}{c|}{ Indikator } \\
\hline Produk Domestik Regional Bruto (PDRB) & $\mathrm{G}_{\mathrm{t}}=\frac{\text { PDRB }_{\mathrm{t}}-\mathrm{PDRB}_{\mathrm{t}-1}}{\mathrm{PDRB}_{\mathrm{t}-1}}$ X 100 \\
\hline Penanaman Modal Asing (PMA) & Total Penanaman Modal Asing (PMA). \\
\hline Penanaman Modal Dalam Negeri (PMDN) & Total Penanaman Modal Dalam Negeri (PMDN). \\
\hline Dana Pihak Ketiga Perbankan Syariah (DPKPS) & DPKPS = Tabungan + Deposito + Giro \\
\hline Pembiayaan Perbankan Syariah (PEMBPS) & Total Pembiayaan. \\
\hline
\end{tabular}




\subsection{Analisis Data}

Langkah pertama yang dilakukan dalam analisis Var adalah melakukan transformasi data dalam bentuk logaritma natural (ln) untuk mendapatkan hasil yang konsisten dan valid. Setalah dilakukan transformasi, selanjutnya melakukan unit root test, yang Tujuannya untuk mengetahui apakah data yang digunakan stasioner pada level atau tidak. Jika data stasioner pada level, maka model VAR in level dapat dilakukan. Namun, apabila data stasioner pada tingkat pertama (First Difference) atau stasioner pada tingkat kedua (Second Difference), maka dapat menggunakan model VAR in difference atau VECM jika dapat kointegrasi (Prawoto, 2019).

Tahapan dalam menggunakan model VAR/VECM adalah uji stasioneritas data dengan Augmented Dickey Fuller (ADF) Test taraf nyata 5\% $(\alpha=5 \%)$; uji stabilitas model VAR untuk mengetahui kestabilan seluruh variabel, dengan nilai modulus
$(<1)$; uji panjang lag optimal dengan melihat lag terpendek dari Akaike Information Criterion (AIC), Schwarz Information Criterion (SC) dan HannanQuin Criterion (HQ); analisis kausalitas granger untuk mengetahui keterpengaruhan antar variabel; uji kointegrasi untuk mengetahui kointegrasi pada variabel-variabel yang digunakan dalam model, dengan menggunakan metode Johansen's Cointegration Test; Vector Error Correction Model (VECM) untuk melihat hubungan jangka panjang dan jangka pendek pada variabel penelitian; anaisis Impuls Response Function (IRF) untuk melihat guncangan dari satu variabel lain dan berapa lama pengaruh tersebut terjadi; analisis Forecast Error Variance Decomposition (FEVD) untuk melihat proporsi pergerakan secara berurutan yang terjadi karena adanya guncangan sendiri dan variabel lain (Prawoto, 2019).

\section{HASIL DAN PEMBAHASAN}

\subsection{Hasil penelitian}

Uji Stasioneritas Data

Tabel 3

Hasil Uji Stasioneritas test for unit root in level, 1st Difference, 2nd Difference Augmented Dickey-Fuller (ADF) test statistic

\begin{tabular}{|c|c|c|c|c|c|c|c|}
\hline \multirow{2}{*}{ No. } & \multirow{2}{*}{ Variabel } & \multicolumn{3}{|c|}{ ADF t-Statistic } & \multicolumn{3}{c|}{ Prob* $^{*}$} \\
\cline { 3 - 8 } & & Level & $\begin{array}{c}\text { 1st } \\
\text { Difference }\end{array}$ & $\begin{array}{c}\text { 2nd } \\
\text { Difference }\end{array}$ & Level & $\begin{array}{c}\text { 1st } \\
\text { Difference }\end{array}$ & $\begin{array}{c}\text { 2nd } \\
\text { Difference }\end{array}$ \\
\hline 1 & PDRB & -2.655550 & -0.604147 & -8.882686 & $\mathbf{0 . 0 8 4 9}$ & $\mathbf{0 . 9 7 6 8}$ & $\mathbf{0 . 0 0 0 0}$ \\
2 & PMDN & -2.490637 & -6.931855 & -6.555043 & $\mathbf{0 . 1 2 0 2}$ & $\mathbf{0 . 0 0 0 0}$ & $\mathbf{0 . 0 0 0 0}$ \\
3 & PMA & -3.690566 & -7.374450 & -6.932919 & $\mathbf{0 . 0 0 5 4}$ & $\mathbf{0 . 0 0 0 0}$ & $\mathbf{0 . 0 0 0 0}$ \\
4 & DPKPS & -2.419957 & -14.133840 & -7.706233 & $\mathbf{0 . 1 3 8 3}$ & $\mathbf{0 . 0 0 0 0}$ & $\mathbf{0 . 0 0 0 0}$ \\
5 & PEMBPS & -2.186664 & -19.054140 & -12.50513 & $\mathbf{0 . 2 1 2 2}$ & $\mathbf{0 . 0 0 0 0}$ & $\mathbf{0 . 0 0 0 0}$ \\
\hline
\end{tabular}

Sumber: data diolah dengan Eviews 9

Hasil pengujian stasioneritas data pada tabel 3 di atas dapat dilihat bahwa pada tingkat level hanya satu variabel yang stasioner, dengan melihat nilai probabilitas lebih kecil dari $0,05 \%$. Selanjutnya, pada 1st Difference terdapat satu variabel yang tidak stasioner. Maka langkah selanjutnya, untuk mendapatkan keseluruhan data stasioner adalah dengan melakukan pengujian pada 2nd Difference. Pada 2nd Difference kelima variabel sudah stasioner.

\section{Uji Stabilitas Model VAR}

Inverse Roots of AR Characteristic Polynomial

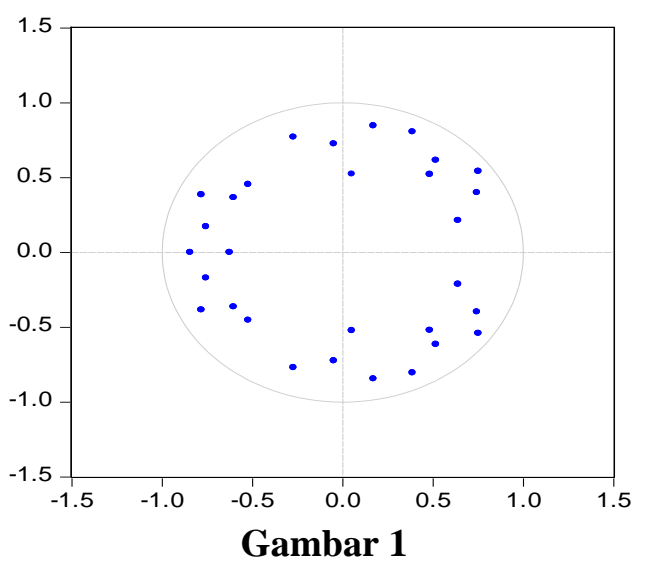

Hasil Uji Stabilitas Model Var

Sumber: data diolah dengan Eviews 9 
Hasil dari pengujian stabilitas model VAR dengan lag optimal bernilai 1-6, menunjukkan semua Uji Panjang Lag Optimal titik-titiknya menyebar di dalam lingkaran gambar dan nilai keseluruhan modulus lebih kecil dari 1 (satu), yang artinya model VAR yang dibentuk stabil.

Tabel 4

VAR Lag Order Selection Criteria

\begin{tabular}{cllllll}
\hline Lag & LogL & LR & FPE & AIC & SC & HQ \\
\hline 0 & 469.7811 & NA & $5.75 \mathrm{e}-11$ & -9.389518 & $-9.258451^{*}$ & -9.336488 \\
1 & 516.7150 & 88.17878 & $3.70 \mathrm{e}-11$ & -9.832626 & -9.046226 & $\mathbf{- 9 . 5 1 4 4 4 8 *}$ \\
2 & 541.6763 & 44.37571 & $3.71 \mathrm{e}-11$ & -9.831845 & -8.390112 & -9.248518 \\
3 & 581.9266 & $67.49028^{*}$ & $2.75 \mathrm{e}-11^{*}$ & $-10.13993^{*}$ & -8.042864 & -9.291454 \\
4 & 601.8455 & 31.38738 & $3.11 \mathrm{e}-11$ & -10.03728 & -7.284883 & -8.923657 \\
5 & 611.7563 & 14.61590 & $4.35 \mathrm{e}-11$ & -9.732450 & -6.324717 & -8.353675 \\
6 & 637.2569 & 35.03121 & $4.51 \mathrm{e}-11$ & -9.742564 & -5.679498 & -8.098641 \\
\hline
\end{tabular}

* indicates lag order selected by the criterion

LR: sequential modified LR test statistic (each test at 5\% level)

FPE: Final prediction error

AIC: Akaike information criterion

SC: Schwarz information criterion

HQ: Hannan-Quinn information criterion

Sumber: data diolah dengan Eviews 9

Hasil dari pengujian lag optimal VAR Lag Order Selection Criteria pada tabel 4.10 di atas menunjukkan bahwa lag terpendek berdasarkan kriteria Hannan-Quin Criterion (HQ) optimal pada lag 1, yang dapat dilihat dengan adanya tanda bintang $(*)$.

\section{Uji Kausalitas Granger}

Tabel 5

Hasil Uji Kausalias Granger

Pairwise Granger Causality Tests

Lags: 1

\begin{tabular}{|c|c|c|c|}
\hline Null Hypothesis: & Obs & F-Statistic & Prob. \\
\hline 1. LNPDRB does not Granger Cause LNPMDN & & 11.4130 & 0.0010 \\
\hline 2. LNPDRB does not Granger Cause LNDPKPS & & 4.92888 & 0.0282 \\
\hline 3. LNPDRB does not Granger Cause LNPEMBPS & & 32.4086 & 8.E-08 \\
\hline 4. LNDPKPS does not Granger Cause LNPMDN & 121 & 12.8849 & 0.0005 \\
\hline 5. LNPEMBPS does not Granger Cause LNPMDN & 121 & 9.76060 & $\mathbf{0 . 0 0 2 2}$ \\
\hline 6. LNPMDN does not Granger Cause LNPEMBPS & & 4.29597 & 0.0404 \\
\hline 7. LNDPKPS does not Granger Cause LNPEMBPS & & 48.6826 & $\overline{1 . E-10}$ \\
\hline
\end{tabular}

Sumber: data diolah dengan Eviews 9

Hasil dari pengujian kausalitas granger pada tabel 5 di atas, menunjukkab bahwa terdapat hubungan kausalitas satu arah dari $\mathrm{Y}$ ke $\mathrm{X}$, yaitu hubungan kausalitas PDRB terhadap PMDN, hubungan kausalitas PDRB terhadap DPKPS dan PDRB terhadap PEMBPS. Kausalitas umpan balik, yaitu hubungan kausalitas PEMBPS terhadap PMDN dan sebaliknya hubungan kausalitas PMDN terhadap PEMBPS. Selain itu, terdapat hubungan kausalitas DPKPS terhadap PMDN dan hubungan kausalitas DPKPS terhadap PEMBPS. 
Uji Kointegrasi

Tabel 6

Hasil Uji Kointegrasi

Lags interval (in first differences): 1 to 1

Unrestricted Cointegration Rank Test (Trace)

\begin{tabular}{ccccc}
\hline $\begin{array}{c}\text { Hypothesized } \\
\text { No. of CE(s) }\end{array}$ & Eigenvalue & Trace & 0.05 & \\
\hline None $*$ & 0.239987 & 93.28211 & 69.81889 & Prob.** \\
\hline At most $1 *$ & 0.227100 & 61.44936 & 47.85613 & 0.0002 \\
At most $2 *$ & 0.139745 & 31.56707 & 29.79707 & 0.0016 \\
At most 3 & 0.080258 & 14.10596 & 15.49471 & 0.0309 \\
At most $4 *$ & 0.037231 & 4.401210 & 3.841466 & 0.0359 \\
\hline
\end{tabular}

Trace test indicates 3 cointegrating eqn(s) at the 0.05 level

$*$ denotes rejection of the hypothesis at the 0.05 level

**MacKinnon-Haug-Michelis (1999) p-values

Unrestricted Cointegration Rank Test (Maximum Eigenvalue)

\begin{tabular}{ccccc}
\hline $\begin{array}{c}\text { Hypothesized } \\
\text { No. of CE(s) }\end{array}$ & Eigenvalue & $\begin{array}{c}\text { Max-Eigen } \\
\text { Statistic }\end{array}$ & $\begin{array}{c}0.05 \\
\text { Critical Value }\end{array}$ & Prob.** \\
\hline None & 0.239987 & 31.83275 & 33.87687 & 0.0860 \\
At most $1 *$ & 0.227100 & 29.88228 & 27.58434 & 0.0249 \\
At most 2 & 0.139745 & 17.46111 & 21.13162 & 0.1513 \\
At most 3 & 0.080258 & 9.704750 & 14.26460 & 0.2321 \\
At most $4 *$ & 0.037231 & 4.401210 & 3.841466 & 0.0359 \\
\hline
\end{tabular}

Max-eigenvalue test indicates no cointegration at the 0.05 level

$*$ denotes rejection of the hypothesis at the 0.05 level

***MacKinnon-Haug-Michelis (1999) p-values

Sumber: data diolah dengan Eviews 9

Hasil dari pengujian kointegrasi dengan trace statistic dan max-eigen statistic pada lag 1 menunjukkan bahwa untuk masing-masing persamaan hanya terdapat tiga rank kointegrasi pada taraf nyata $5 \%$ dengan tanda bintang (*). Dengan demikian, maka persamaan harus diselesaikan dengan metode VECM.

Vector Error Correction Model (VECM)

Tabel 7

Hasil Estimasi VECM Jangka Panjang

\begin{tabular}{||c|c|c|c|}
\hline $\begin{array}{c}\text { Variabel } \\
\text { Endogen }\end{array}$ & $\begin{array}{c}\text { Variabel } \\
\text { Eksogen }\end{array}$ & Koefisien & T-Statistik \\
\hline \multirow{4}{*}{ D(LNPDRB) } & $\mathrm{C}$ & -9.177079 & \\
\cline { 2 - 4 } & LNPMDN (-1) & 0.030575 & {$[2.15334]$} \\
\cline { 2 - 4 } & LNPMA (-1) & 0.058736 & {$[3.78988]$} \\
\cline { 2 - 4 } & LNDPKPS (-1) & -0.662435 & {$[-8.71578]$} \\
\cline { 2 - 4 } & LNPEMBPS (-1) & 0.462455 & {$[4.53409]$} \\
\hline
\end{tabular}

Sumber: data diolah dengan Eviews 9

Berdasarkan tabel 7 di atas dapat diketahui keterpengaruhan variabel dari persamaan jangka panjang, antara lain:

a. Variabel PMDN berpengaruh positif dan signifikan terhadap PDRB Sumatera Utara.

b. Variabel PMA berpengaruh positif dan signifikan terhadap PDRB Sumatera Utara.

c. Variabel DPKBS berpengaruh negatif terhadap PDRB Sumatera Utara.

d. Variabel PEMBPS berpengaruh positif dan signifikan terhadap PDRB Sumatera Utara.

Tabel 8

Hasil Estimasi VECM Jangka Pendek

\begin{tabular}{|c|c|c|c|}
\hline $\begin{array}{l}\text { Variabel } \\
\text { Endogen }\end{array}$ & $\begin{array}{l}\text { Variabel } \\
\text { Eksogen }\end{array}$ & $\mathrm{K}$ & $\begin{array}{c}\mathrm{T}- \\
\text { Statistik }\end{array}$ \\
\hline \multirow{2}{*}{ D(LNPDRB) } & CointEq1 & -0.014355 & {$[-1.32435]$} \\
\hline & $\mathrm{D}($ LNPDRB(-1)) & 0.498646 & [5.78678] \\
\hline \multirow{2}{*}{ D(LNPMDN) } & CointEq1 & -1.560673 & {$[-1.66508]$} \\
\hline & $\mathrm{D}(\mathrm{LNP}$ & & [2.15105] \\
\hline \multirow{3}{*}{ D(LNPMA) } & CointEq1 & -1.153300 & {$[-2.03853]$} \\
\hline & D(LNPMDN(-1)) & 0.180741 & [3.02151] \\
\hline & D(LNPMA(-1)) & 0.490596 & [4.53980] \\
\hline \multirow{2}{*}{ D(LNDPKPS) } & CointEq1 & -0.036801 & {$[-0.63618]$} \\
\hline & $\overline{\mathrm{D}(\mathrm{LNDPKPS}(-1))}$ & -0.276250 & {$[-2.61700]$} \\
\hline \multirow[b]{2}{*}{ D(LNPEMBPS) } & CointEq1 & -0.792025 & {$[-4.43836]$} \\
\hline & $\begin{array}{l}\text { D(LNPEMBPS(- } \\
\text { 1)) }\end{array}$ & -0.301740 & 8 \\
\hline
\end{tabular}

Sumber: data diolah dengan Eviews 9 
Dari tabel 8 di atas dapat dilihat bahwa hasil estimasi VECM dalam jangka pendek variabel yang memiliki pengaruh terhadap variabel lain adalah

\section{Analisis Impluse Response Fanction (IRF)}
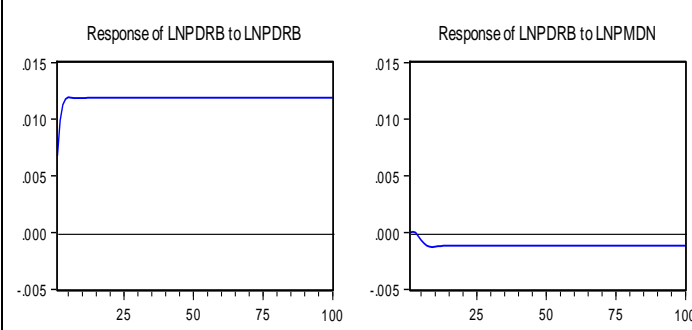

Response to Cholesky One S.D. Innovations
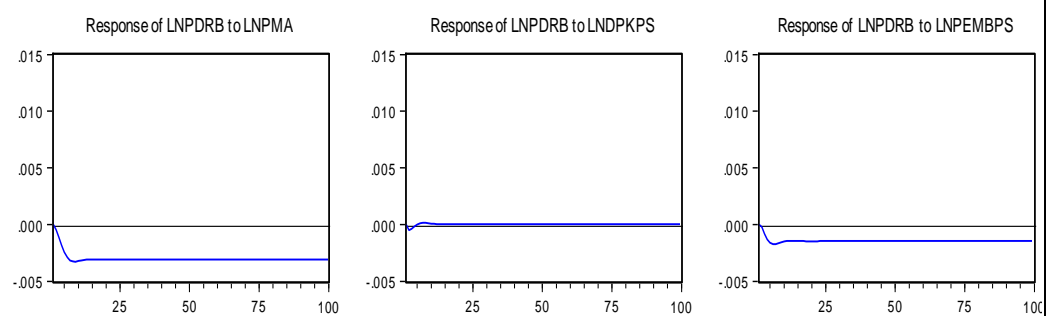

Response of LNPMDN to LNPDRB
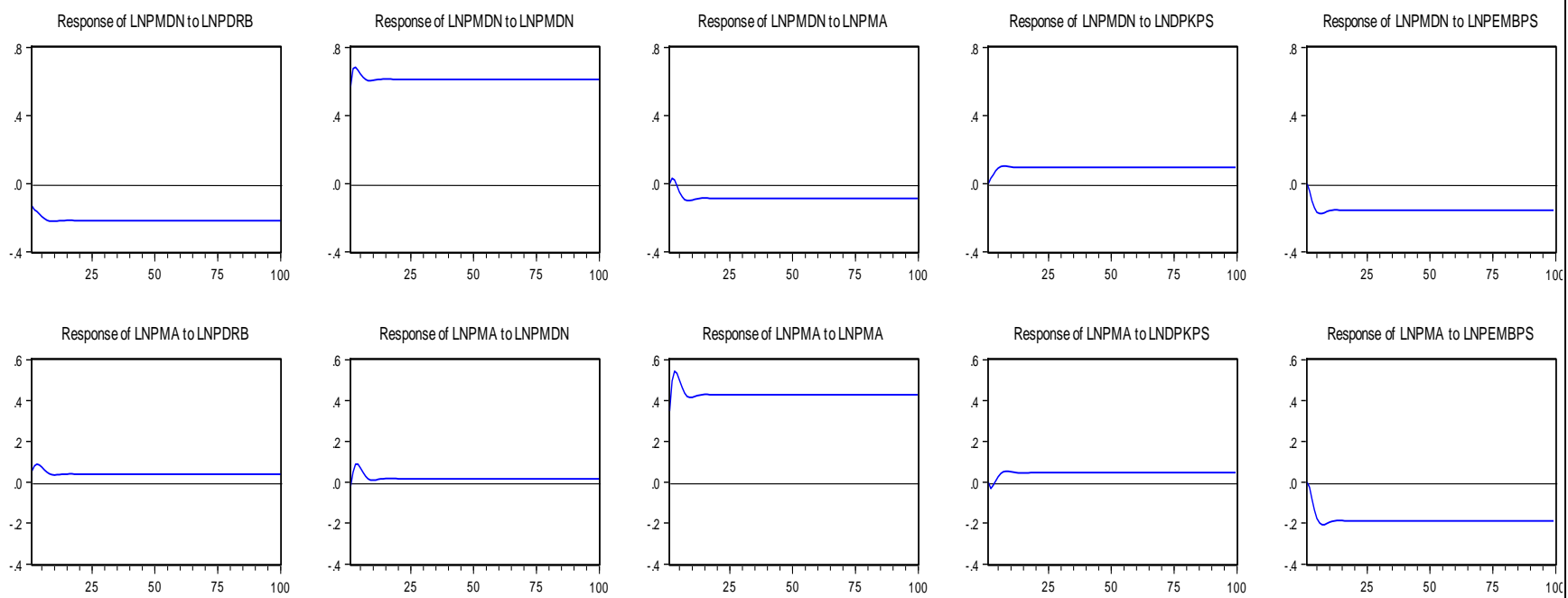

Response of LNDPKPS to LNPDRB
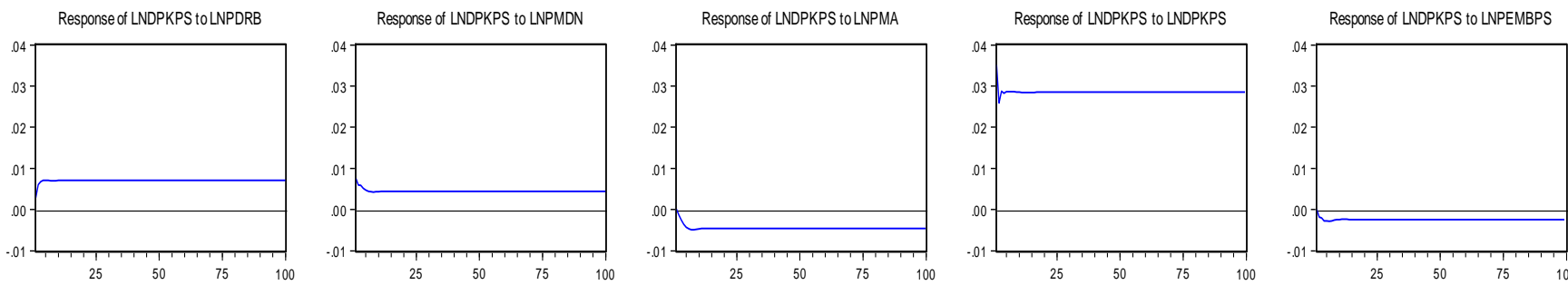

Response of LNPEMBPS to LNPDRB
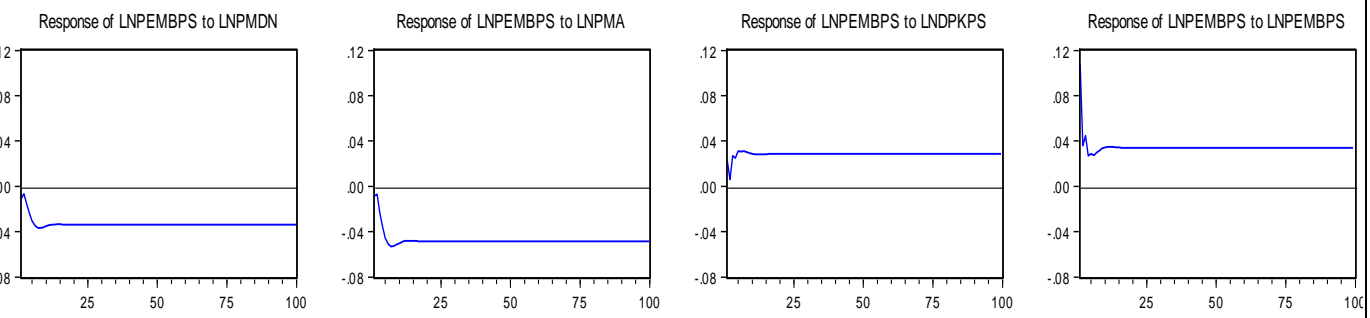

Impulse Response to Cholesky (d.f. adjusted) One S.D. Innovations

Sumber: data diolah dengan Eviews 9

Dari hasil analisis Impulse Response Function (IRF) pada gambar 1 di atas menunjukkan bahwa seluruh variabel dalam jangka pendek stabil dan sedikit merespon guncangan yang terjadi. 


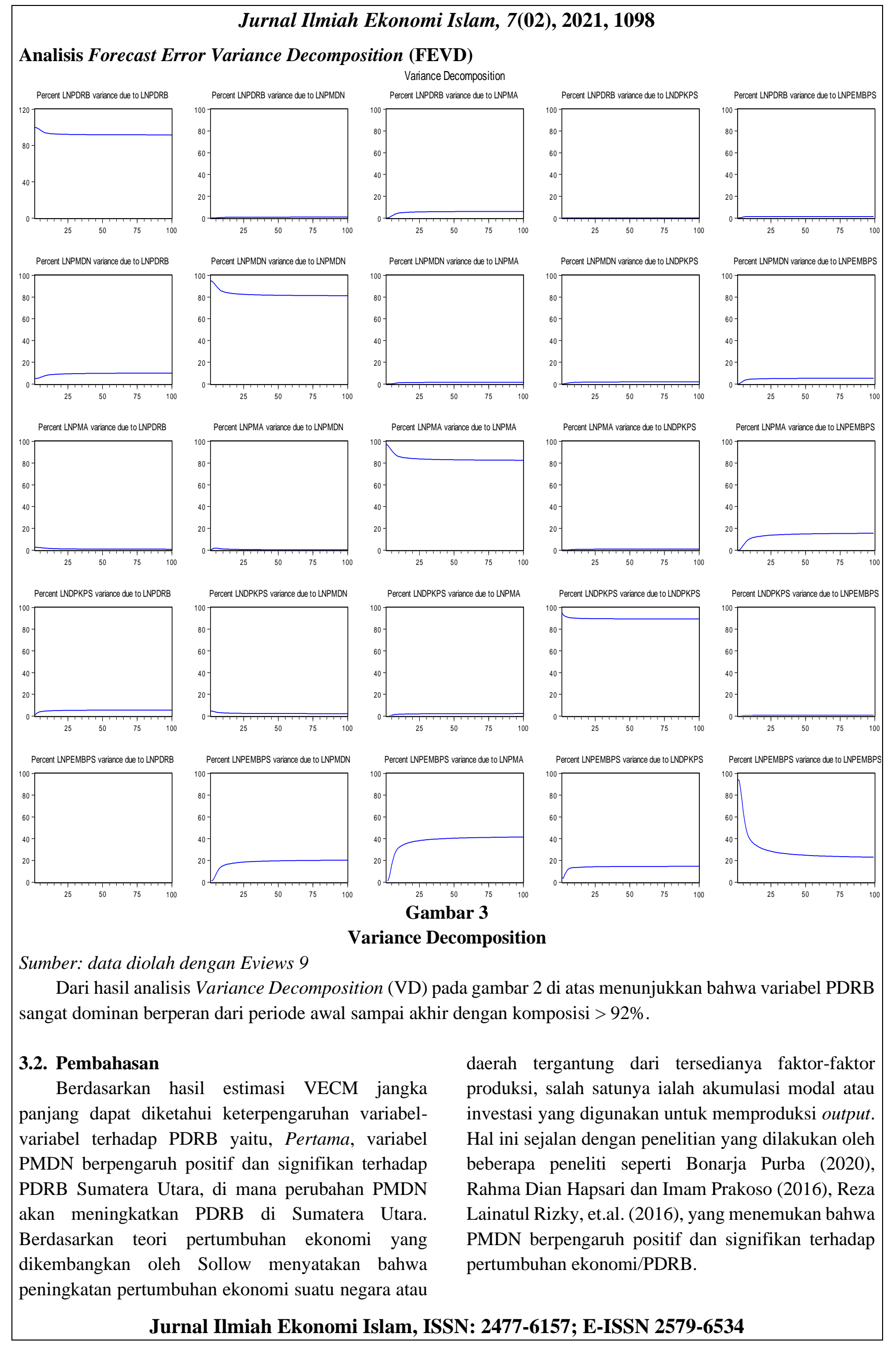


Kedua, PMA berpengaruh positif dan signifikan terhadap PDRB Sumatera Utara, di mana perubahan PMA akan meningkatkan PDRB di Sumatera Utara. Menurut penelitian yang telah dilakukan oleh Khoirul Ifa dan Fitria Ardiansyah, menemukan bahwa terdapat pengaruh PMA terhadap PDRB, dimana perubahan pembentukan modal pada suatu masa dapat memberikan kemampuan perekonomian untuk menghasilkan barang dan jasa yang lebih besar (Ifa \& Ardiansyah, 2019). Adapun penelitian lainnya yang menemukan hasil yang sama ialah Annisa Masruri Zaimsyaha dan Sri Herianingrum (2019), Ahmad Jazuli Rahman, et.al. (2016), Muhammad Kholis, et.al. (2016).

Ketiga, DPKPS berpengaruh negatif terhadap PDRB, di mana perubahan DPKPS akan menurunkan PDRB di Sumatera Utara. Menurut penelitian yang telah dilakukan oleh Salahuddin El Ayyubi, menemukan bahwa DPKPS memiliki hubungan negatif terhadap pertumbuhan ekonomi. Hal ini terjadi karena adanya fenomena displace commercial risk, yang artinya ketika suku bunga DPK perbankan konvensional meningkat, maka nasabah akan memindahkan tabungannya pada perbankan konvensional, daripada tetap menyimpankan tabungannya pada perbankan syariah (Ayyubi et al., 2019).

Keempat, PEMBPS berpengaruh positif dan signifikan terhadap PDRB Sumatera utara, yang mana jika terjadi perubahan PEMBPS maka akan meningkatkan PDRB di Sumatera Utara. Hal ini sejalan dengan penelitian yang dilakukan oleh Annisa Masruri Zaimsyaha dan Sri Herianingrum, menemukan bahwa apabila pembiayaan yang disalurkan oleh Bank Syariah meningkat, maka akan berdampak pada perekonomian suatu negara. Karena Bank Syariah dapat memberikan pembiayaan kepada masyarakat untuk kegiatan usaha yang dilakukan oleh masyarakat tersebut (Zaimsyaha \& Herianingrum, 2019). Sehingga dapat mensejahterakan masyarakat di suatu daerah tersebut. Adapun penelitian terdahulu lainnya yang sejalan adalah Muhammad Nasir (2020), Muhammad Yasir Saeed, et.al. (2020), Hazimi Foziah et.al. (2020), Moh. Herman Eko Santoso dan Mohamad Soleh Nurzaman (2020), Meri Anggraini (2019), Salahuddin El Ayyubi (2017), Ade Ananto Terminanto dan Ali Rama (2017), Purwanto dan Fuad Yanuar A.R (2017).

\section{KESIMPULAN}

Berdasarkan hasil penelitian dengan menggunakan metode VECM, maka dapat disimpulkan bahwa dalam jangka panjang variabel PMDN, PMA dan PEMBPS berpengaruh positif dan signifikan terhadap PDRB Sumatera Utara, sedangkan variabel DPKPS berpengaruh negatif terhadap PDRB Sumatera Utara. Dalam jangka pendek variabel PMDN signifikan mempengaruhi variabel PMA. Berdasarkan hasil penelitian ini, menunjukkan bahwa permodalan sangat diperlukan di dalam mendorong kemajuan perekonomian.

Penelitian ini memberikan kontribusi untuk pemerintah Sumatera Utara dalam meningkatkan perekonomian dengan mendorong dan mendukung kegiatan yang dilakukan oleh penanaman modal dalam negeri dan penanaman modal asing, serta peran perbankan syariah sebagai lembaga keuangan yang menggunakan prinsip syariah di dalam kegiatan operasionalnya, dapat memberikan pembiayaan yang sangat diperlukan bagi pelaku usaha yang memerlukan permodalan.

\section{REFERENSI}

Ascarya. (n.d.). Aplikasi Vector Autorogression dan Vector Error Correction Model Menggunakan Eviews 4.1.

Ayyubi, S. El, Anggraeni, L., \& Mahiswari, A. D. (2019). Pengaruh Bank Syariah terhadap Pertumbuhan Ekonomi di Indonesia Pengaruh Bank Syariah terhadap Pertumbuhan Ekonomi di Indonesia The Effect of Islamic Banking to Economic Growth in Indonesia. April 2018. https://doi.org/10.29244/jam.5.2.88-106

Emilienne, C., Yameogo, W., \& Omojolaibi, J. A. (2020). Trade liberalisation , economic growth and poverty level in sub-Saharan Africa ( SSA ). Economic Research-Ekonomska Istraživanja, $O(0), \quad 1-21$. https://doi.org/10.1080/1331677X.2020.180442 8

Hafizh, M. (2019). Pengaruh Makroekonomi terhadap Dana Pihak Ketiga serta Dampaknya Terhadap Pembiayaan pada Perbankan Syari'ah Di Indonesia.

Hasyim, A. I. (2016). Ekonomi Makro. Kencana.

Ifa, K., \& Ardiansyah, F. (2019). Journals of Economics Development Issues ( JEDI ). 2(1), $48-57$. 
Jurnal Ilmiah Ekonomi Islam, 7(02), 2021, 1100

Jhingan, M. L. (2018). The Economics of Development and Planning (D. Guritno, Ed.). Rajawali Pers.

Kairupan, D. (2013). Aspek Hukum Penanam Modal Asing Di Indonesia. Kencana.

Masykuroh, N., Suganda, A. D., Sani, A. A., Fasa, M. I., Noer, D., \& Rahmanto, A. (2020). Cycle Business on Islamic Bank: Var Approach. 12(3), $1165-1175$.

Nuryanto, R., Tho'in, M., \& Wardani, H. K. (2014). Rasio Likuiditas, Rasio Solvabilitas, Rasio Rentabilitas Koperasi Jasa Keuangan Syariah Di Jawa Tengah. Jurnal Akuntansi dan Pajak, 15(01).

Nurzaman, M. H. E. S. dan M. S. (2020). Asesmen Kontribusi Keuangan Syariah terhadap Pertumbuhan Ekonomi Di Indonesia. Jurnal Ekonomi, Keuangan Dan Perbankan Syariah, 4, $1-15$.

Prawoto, A. T. B. dan N. (2019). Analisis Regresi Dalam Penelitian Ekonomi \& Bisnis: Dilengkapi Aplikasi Spss \& Eviews. Rajawali Pers.

Purba, B. (2020). Jurnal Humaniora Analisis Tentang Pengaruh Investasi Terhadap Pertumbuhan. 4(1), 196-204.

Rama, A. A. T. dan A. (2017). Pengaruh Belanja Pemerintah dan Pembiayaan Bank Syariah Terhadap Pertumbuhan Ekonomi: Studi Kasus Data Panel Provinsi Di Indonesia. Jurnal Kajian Ekonomi Dan Bisnis Islam, 10(1), 99.
Reviews, S. S. (2019). VECTOR AUTO REGRESSION ANALYSIS BETWEEN EXPORT, ECONOMIC GROWTH , AND JOB OPPORTUNITY IN BANGKA BELITUNG. 7(4), 677-684.

Santosa, S., Tho'in, M., \& Sumadi, S. (2020). Analisis Tingkat Kesehatan Bank Syariah Menggunakan Rasio Permodalan, Profitabilitas, Pembiayaan, dan Risiko Kredit. Jurnal Ilmiah Ekonomi Islam, 6(2), 367-371.

Saeed, M. Y., Hamid, K., Ahmad, M., \& Rehman, U. (2020). Islamic Financial Development and Economic Growth of Emerging Economy of Pakistan ; a Panel Data Approach. 6(1), 197207. https://doi.org/10.26710/jbsee.v6i1.1039

Smith, M. P. T. dan S. C. (2011). Economic Development (A. Dharma, Ed.). Erlangga.

Tho'in, M., \& Prastiwi, I. E. (2019). An Analysis the Rupiah Exchange Rates Effect Against the American Dollar and Inflation Against the Growth of Islamic Banking Mudharabah Deposits in Indonesia. International Journal of Islamic Business and Economics (IJIBEC), 3(1), 82-91.

Zaimsyaha, A. M., \& Herianingrum, S. (2019). Jurnal Ilmiah Ekonomi Islam , 5 ( 03 ), 2019, 211-216 Pengaruh Pembiayaan Bank Islam, FDI dan Pertumbuhan Ekonomi: Studi Empiris Negara OKI. 5(03), 211-216. 